\title{
GAMBARAN PENGETAHUAN PASIEN HIPERTENSI TERHADAP PENYAKIT HIPERTENSI DAN OBAT ANTIHIPERTENSI GOLONGAN ACE-INHIBITOR DAN DIURETIK
}

\section{The Overview Knowledge of Hypertension Patient Toward to Hypertension disease and Antihypertension Drug ACE-Inhibitor and Diuretic}

\author{
Denia Pratiwi* \\ *Dosen Program Studi D-III Analisa Farmasi dan Makanan Universitas Abdurrab
}

Email : denia.pratiwi@univrab.ac.id

\begin{abstract}
ABSTRAK
Hipertensi adalah suatu keadaan dimana seseorang mengalami peningkatan tekanan darah diatas angka normal, yaitu 120/80 mmHg. Hipertensi merupakan penyakit yang tidak dapat disembuhkan dan memiliki banyak komplikasi. Pengobatan yang dilakukan bertujuan untuk menurunkan tekanan darah dan mencegah terjadinya komplikasi. Salah satu terapi farmakologi hipertensi adalah menggunakan obat antihipertensi golongan ACE-Inhibitor dan diuretik. Tujuan penelitian ini adalah untuk mengetahui gambaran pengetahuan pasien hipertensi terhadap penyakit hipertensi dan obat antihipertensi, khususnya obat antihipertensi golongan ACE-Inhibitor dan diuretik. Penelitian ini merupakan penelitian deskriptif yang dilaksanakan dengan metode survei. Penelitian dilaksanakan pada bulan Februari 2015 di UPTD Puskesmas Melur dengan jumlah responden sebanyak 81 responden terdiri dari 50 responden untuk obat golongan ACE-Inhibitor dan 31 responden untuk obat golongan diuretik. Secara umum gambaran pengetahuan pasien hipertensi terhadap penyakit hipertensi yang dilakukan di UPTD Puskesmas Melur pada bulan Februari 2015 adalah cukup sebanyak 38 responden (47\%) dan obat antihipertensi golongan ACE-Inhibitor adalah kurang sebanyak 30 responden (60\%) dan obat golongan diuretik adalah cukup sebanyak 16 orang $(52 \%)$.
\end{abstract}

Kata kunci : Pengetahuan, Hipertensi, Obat golongan ACE-Inhibitor dan Diuretik

\section{ABSTRACT}

Hypertension is a circumstances where patient having enhancement blood pressure above the normal rate was $120 / 80 \mathrm{~mm} / \mathrm{Hg}$. Hypertension is a disease can't cured and can make many complication. One of pharmacology treatment can do for decrease blood pressure and prevent complication is using drug ACEInhibitor and diuretic group. The purpose of this research to know an overview of knowledge hypertension patient about the disease and drug ACE-Inhibitor and diuretic group.This is descriptif research using survey method, was done in Februari 2015 at UPTD Puskesmas Melur Pekanbaru with the number of respondent as much 81 patient consist of 50 respondent for ACE-Inhibitor group drug and 31 respondent for diuretic drug. Generally an overview of knowledge hypertension patient toward to hypertension disease was enough as much 38 patient (47\%) and toward to ACE-Inhibitor group was less as much 30 respondent $(60 \%)$ and to diuretic drug was enough as much 16 patient $(52 \%)$.

Keyword : Knowledge, Hypertension, ACE-Inhibitor drug an diuretic drug 


\section{PENDAHULUAN}

Berkembangnya pengetahuan, teknologi dan informasi berdampak besar pada perubahan gaya hidup penduduk yang berdampak kurang baik terhadap kesehatan. Gaya hidup yang kurang baik tersebut merupakan salah satu penyebab munculnya berbagai macam penyakit, salah satunya hipertensi.

Hipertensi merupakan penyakit kronis dengan karakteristik tekanan darah cenderung naik turun sehingga diperlukan pengobatan yang lama bahkan seumur hidup. Gangguan sistem peredaran darah ini menyebabkan kenaikan tekanan darah di atas nilai normal, yaitu melebihi 140/90 mmHg. Berdasarkan etiologi, hipertensi dibedakan menjadi 2, yaitu: hipertensi primer dan hipertensi sekunder [1].

Hipertensi sering disebut sebagai "silent killer" (pembunuh diam-diam), karena seringkali penderita hipertensi bertahun-tahun tanpa merasakan sesuatu gangguan atau gejala. Tanpa disadari penderita mengalami komplikasi pada organ-organ vital seperti jantung, otak, ataupun ginjal. Gejala-gejala akibat hipertensi, seperti pusing, gangguan penglihatan, dan sakit kepala, sering kali terjadi pada saat hipertensi sudah lanjut disaat tekanan darah sudah mencapai angka tertentu yang bermakna [1].

Penelitian di Amerika oleh American Hypertension Association (2006) ditemukan hanya 68\% penderita hipertensi tahu bahwa mereka menderita penyakit tersebut, sisanya mengatakan sama sekali tidak tahu [1].

Di Indonesia, dengan tingkat kesadaran akan kesehatan yang lebih rendah, jumlah pasien yang tidak menyadari bahwa dirinya menderita hipertensi dan yang tidak mematuhi minum obat kemungkinan lebih besar. Dalam lingkup penyakit kardiovaskuler, hipertensi menduduki peringkat pertama dengan penderita terbanyak [1].

Hasil survei awal yang dilakukan di Dinas Kesehatan Kota Pekanbaru, diketahui bahwa penderita hipertensi di UPTD Puskesmas Melur pada tahun 2014 yaitu sebanyak 1.665 orang.

Pengetahuan dan ketidakpatuhan merupakan beberapa faktor yang mempengaruhi pasien hipertensi dalam menjalankan program terapi. Kebanyakan pasien tidak meminum obat antihipertensi dikarenakan kurangnya pengetahuan pasien tentang terapi hipertensi yang di lakukan. Oleh karena itu, sangat penting memberikan edukasi tentang manfaat pengontrolan tekanan darah dan konsumsi obat antihipertensi untuk mencegah naiknya tekanan darah. Selain itu, alasan ketidakpatuhan penderita hipertensi dalam pengobatan adalah kebosanan minum obat karena tekanan darah masih naik turun.

Menurut Mohani [2], sebenarnya bila dibandingkan dengan tiga dekade yang lalu, pengobatan hipertensi sudah mengalami perbaikan. Profil tekanan darah yang didapat pada masyarakat sudah mengalami perubahan, dimana yang awalnya banyak ditemui hipertensi dengan derajat yang berat, sekarang sudah mengalami penurunan. Selain itu jenis obat antihipertensi sudah semakin banyak dengan tingkat efikasi yang meningkat bila dibandingkan dengan beberapa waktu yang lalu, sehingga akan lebih mudah untuk mencapai target tekanan darah seperti yang sudah dianjurkan dengan mempergunakan berbagai macam obat yang telah ada. Golongan obat antihipertensi adalah obat golongan ACE-Inhibitor, Calcium Channel Blocker, $\beta$ bloker,Angiotensin Reseptor Blocker dan diuretik.

Obat golongan ACE inhibitor (Angiotensin Converting Enzyme) merupakan salah satu golongan obat yang paling banyak digunakan bekerja dengan cara mencegah konstriksin (pengkerutan) pembuluh darah akibat formasi hormon angiotensin II dengan cara memblokade enzim ACE, mencegah pembentukan angiotensin I menjadi angiotensin II. Obat-obat ini terbukti sangat berguna untuk pengobatan hipertensi karena khasiat dan profil efek sampingnya yang lebih baik, sehingga meningkatkan kepatuhan pasien.

Obat antihipertensi golongan diuretik merupakan salah satu golongan obat yang paling sering dikombinasikan dengan obat antihipertensi lain. Banyaknya penggunaan obat anti hipertensi ini karena obat ini dinilai paling aman dan efektif dalam menurunkan tekanan darah [3]. Mekanisme kerja obat diuretik ini menurunkan tekanan darah dengan cara membantu fungsi ginjal untuk menyaring dan membuang garam dan air, yang akan mengurangi volume cairan di seluruh tubuh sehingga menurunkan tekanan darah.

Berdasarkan uraian latar belakang diatas, maka penulis tertarik untuk melihat gambaran pengetahuan pengetahuan pasien hipertensi terhadap penyakit hipertensi dan obat antihipertensi golongan ACE-Inhibitor dan diuretik. 


\section{METODE PENELITIAN}

\section{a. Desain Penelitian}

Penelitian ini merupakan penelitian kuantitatif dengan jenis desain deskriptif yang dilaksanakan dengan menggunakan metode survei.

\section{b. Populasi dan Sampel}

Populasi dalam penelitian ini adalah seluruh penderita hipertensi rawat jalan yang berobat di UPTD Puskesmas Melur dan diberi obat antihipertensi golongan diuretik atau obat golongan ACE-Inhibitor. Pada penelitian ini sampel diambil secara purposive sampling. Kriteria inklusi: bersedia menjadi responden, menderita hipertensi bukan untuk yang pertama kali, berumur > 18 tahun, mendapat obat antihipertensi golongan ACE-Inhibitor /diuretik. Kriteria eksklusi: Penderita hipertensi untuk yang pertama kali, mendapat obat antihipertensi selain golongan diuretik atau golongan ACE-Inhibitor.

\section{c. Tempat dan Waktu Penelitian}

Penelitian ini dilakukan di UPTD Puskesmas Melur Pekanbaru pada bulan Februari tahun 2015.

\section{d. Alat Pengumpulan Data}

Untuk memperoleh informasi dari responden, peneliti menggunakan alat pengumpulan data berupa kuesioner dengan menggunakan daftar pertanyaan kombinasi terbuka dan tertutup. Jumlah pertanyaan yang diberikan sebanyak 14 yang terdiri dari: data responden sebanyak 3 pertanyaan, pengetahuan pasien tentang hipertensi sebanyak 6 pertanyaan, dan pengetahuan pasien tentang obat antihipertensi golongan ACEInhibitor dan golongan diuretik sebanyak 5 pertanyaan. Kuesioner berupa daftar pertanyaan yang dikutip dari jurnal Nita pada tahun 2012.

\section{e. Prosedur Pengolahan Data}

Di dalam pengolahan data, penulis melakukan secara manual. Setelah data terkumpul kemudian diolah dengan mengikuti langkah-langkah sebagai berikut:

1. Pemeriksaan data (Editing)

2. Pemeriksaan kode : data yang diperoleh diberi kode tertentu untuk mempermudah pembacaan data.

3. Telly : setelah dilakukan coding, data ditelly untuk mendapatkan jumlah dan frekuensi untuk melakukan analisa data dan selanjutnya disajikan dalam bentuk tabel.

4. Cleaning : merupakan kegiatan pengecekan kembali data yang sudah diproses apakah ada kesalahan atau tidak.

5. Tabulasi : sebagai proses penyusunan data kedalam bentuk tabel-tabel.

\section{f. Analisis Data}

Data diolah dan dianalisis secara deskriptif. Disajikan dalam bentuk distribusi frekuensi (tabel atau grafik). Skor bagi jawaban benar adalah 1, sedangkan skor bagi jawaban yang salah dan tidak tahu adalah 0 .

Rumus:

$$
\mathrm{P}=\frac{\mathrm{F}}{\mathrm{N}} \quad \mathrm{X} 100 \%
$$

$\begin{array}{ll}\text { Keterangan: } & \mathrm{P}: \text { persentase } \\ & \mathrm{F}: \text { frekuensi } \\ & \mathrm{N}: \text { jumlah seluruh observasi }\end{array}$


Kriteria tingkat pengetahuan:

Nilai $76-100 \%$ : baik

Nilai $56-75 \%$ : cukup

Nilai $0-55 \%$ : kurang

a. Baik, apabila responden mendapat nilai $76-100 \%$ yaitu responden menjawab 9-11 pertanyaan yang disediakan.

b. Cukup, apabila responden mendapat nilai 56-75\% yaitu menjawab dengan benar 7-8 dari 11 pertanyaan yang disediakan.

c. Kurang, apabila responden mendapat nilai $<55 \%$ yaitu menjawab dengan benar 1-6 dari 11 pertanyaan yang disediakan.

\section{g. Definisi Operasional}

Definisi operasional berfungsi untuk menyederhanakan arti kata atau pemikiran tentang ide-ide, hal dan kata-kata yang digunakan agar orang lain dapat memahami maksudnya sesuai dengan keinginan peneliti (Notoatmodjo, 2005).

Tabel I. Definisi Operasional

\begin{tabular}{|c|c|c|c|c|}
\hline Variable & Sub Variable & Definisi Operasional & Alat Ukur & Hasil ukur \\
\hline Pengetahuan & & $\begin{array}{l}\text { Hasil dari tahu dan ini } \\
\text { terjadi setelah orang } \\
\text { melakukan } \\
\text { pengindraan }\end{array}$ & Kuesioner & $\begin{array}{l}\text { Baik } 76-100 \% \\
\text { Cukup 56-75\% } \\
\text { Kurang 0-55\% }\end{array}$ \\
\hline & $\begin{array}{l}\text { Pengetahuan } \\
\text { hipertensi }\end{array}$ & $\begin{array}{l}\text { Hipertensi yang } \\
\text { meliputi pengertian, } \\
\text { komplikasi, gejala } \\
\text { hipertensi tujuan } \\
\text { terapi, cara terapi, dan } \\
\text { konsumsi obat. }\end{array}$ & Kuesioner & $\begin{array}{l}\text { Baik 76-100\% } \\
\text { Cukup 56-75\% } \\
\text { Kurang 0-55\% }\end{array}$ \\
\hline & $\begin{array}{l}\text { Obat } \bigcirc \\
\text { antihipertensi } \\
\text { golongan } \\
\text { diuretic }\end{array}$ & $\begin{array}{l}\text { Hipertensi yang } \\
\text { meliputi jenis obat } \\
\text { yang dikonsumsi, } \\
\text { waktu konsumsi, cara } \\
\text { mengkonsumsi dan } \\
\text { efek samping obat. }\end{array}$ & Kuesioner & $\begin{array}{l}\text { Baik } 76-100 \% \\
\text { Cukup 56-75\% } \\
\text { Kurang 0-55\% }\end{array}$ \\
\hline
\end{tabular}




\section{HASIL DAN DISKUSI}

Penelitian yang dilakukan pada bulan Februari 2015 di UPTD Puskesmas Melur berdasarkan kriteria yang ditetapkan penulis, diperoleh hasil sebagai berikut:

1. Data Demografi Responden

Tabel II. Data Demografi Responden

\begin{tabular}{|c|c|c|}
\hline Parameter & Frekuensi & Persentase \\
\hline \multicolumn{3}{|l|}{ Umur (tahun) } \\
\hline $36-45$ & 12 & $15 \%$ \\
\hline $45-65$ & 40 & $49 \%$ \\
\hline$>65$ & 29 & $36 \%$ \\
\hline \multicolumn{3}{|l|}{ Jenis Kelamin } \\
\hline Laki-laki & 30 & $37 \%$ \\
\hline Perempuan & 51 & $63 \%$ \\
\hline \multicolumn{3}{|l|}{ Pendidikan } \\
\hline SD & 28 & $34.5 \%$ \\
\hline SMP & 28 & $34.5 \%$ \\
\hline SMA & 17 & $21 \%$ \\
\hline Perguruan Tinggi & 8 & $10 \%$ \\
\hline Total & 81 & $100 \%$ \\
\hline
\end{tabular}

Berdasarkan tabel II, diketahui bahwa responden sebagian besar (49\%) berusia antara 45-65 tahun. Perempuan sebanyak 63\% dan laki-laki 37\%. Distribusi tingkat pendidikan untuk pendidikan terakhir SD dan SMP memiliki jumlah yang sama yaitu masing-masing sebanyak 28 responden (34.5\%), pendidikan terakhir SMA sebanyak 17 responden $(21 \%)$, dan pendidikan terakhir Perguruan Tinggi sebanyak 8 responden $(10 \%)$.

\section{Tabel III. Data Responden yang Berhubungan dengan Penyakit Hipertensi}

\begin{tabular}{ccc}
\hline Lama menderita hipertensi & Frekuensi & Persentase \\
\hline 1 tahun & & 28 \\
$1-5$ Tahun & 23 & $28.5 \%$ \\
$6-10$ tahun & 21 & $26 \%$ \\
\hline 10 tahun & 2 & $2.5 \%$ \\
Frekuensi ke Dokter & & \\
Sebulan Sekali & 16 & $20 \%$ \\
3 Bulan Sekali & 0 & $0 \%$ \\
6 Bulan Sekali & 0 & $0 \%$ \\
Tidak Teratur & 65 & $80 \%$ \\
Mendapat Penyuluhan Hipertensi & & \\
Pernah & 36 & $44 \%$ \\
Tidak & 45 & $56 \%$ \\
\hline Total & 81 & $100 \%$ \\
\hline
\end{tabular}

Dari tabel III tampak bahwa $43 \%$ responden telah menderita hipertensi sejak 1-5 tahun. Sebagian responden memeriksakan dirinya secara tidak teratur yaitu $80 \%$. Responden yang mendapat penyuluhan tentang hipertensi yaitu 36 responden (44\%), lebih kecil dibandingkan pada responden yang tidak pernah mendapatkan penyuluhan yaitu 45 responden $(56 \%)$. 
2. Tingkat Pengetahuan Responden Tentang Hipertensi

Tabel IV. Distribusi Frekuensi Tingkat Pengetahuan Responden Tentang Hipertensi

\begin{tabular}{ccc}
\hline Kategori & Frekuensi & Persentase \\
\hline Baik & 26 & $32 \%$ \\
Cukup & 38 & $47 \%$ \\
Kurang & 17 & $21 \%$ \\
\hline Total & 81 & $100 \%$ \\
\hline
\end{tabular}

Berdasarkan tabel IV, diketahui bahwa pengetahuan responden tentang hipertensi dikategorikan baik sebanyak 26 orang (32\%), kategori cukup sebanyak 38 orang (47\%) dan kategori kurang sebanyak 17 orang $(21 \%)$.

3. Tingkat Pengetahuan Responden tentang obat ACE-inhibitor

Tabel V. Distribusi Frekuensi Tingkat Pengetahuan Responden Tentang Obat Antihipertensi golongan ACE-inhibitor

\begin{tabular}{ccc}
\hline Kriteria & Frekuensi & Persentase (\%) \\
\hline Baik & 3 & $6 \%$ \\
Cukup & 17 & $34 \%$ \\
Kurang & 30 & $60 \%$ \\
\hline Total & 50 & 100 \\
\hline
\end{tabular}

Berdasarkan tabel V, diketahui bahwa pengetahuan responden tentang obat golongan ACE-Inhibitor dikategorikan baik sebanyak 3 orang (6\%), kategori cukup sebanyak 17 orang (34\%) dan kategori kurang sebanyak 30 orang $(60 \%)$.

4. Tingkat Pengetahuan Responden Tentang Obat Antihipertensi Golongan Diuretik

Tabel VI. Distribusi Frekuensi Tingkat Pengetahuan Responden Tentang Obat Antihipertensi Golongan Diuretik

\begin{tabular}{ccc}
\hline Kategori & Frekuensi & Persentase \\
\hline Baik & 2 & $6 \%$ \\
Cukup & 16 & $52 \%$ \\
Kurang & 13 & $42 \%$ \\
\hline Total & 31 & $100 \%$ \\
\hline
\end{tabular}

Berdasarkan tabel VI, diketahui bahwa pengetahuan responden tentang obat golongan diuretik dikategorikan baik sebanyak 2 orang (6\%), kategori cukup sebanyak 16 orang (52\%) dan kategori kurang sebanyak 13 orang (42\%). 


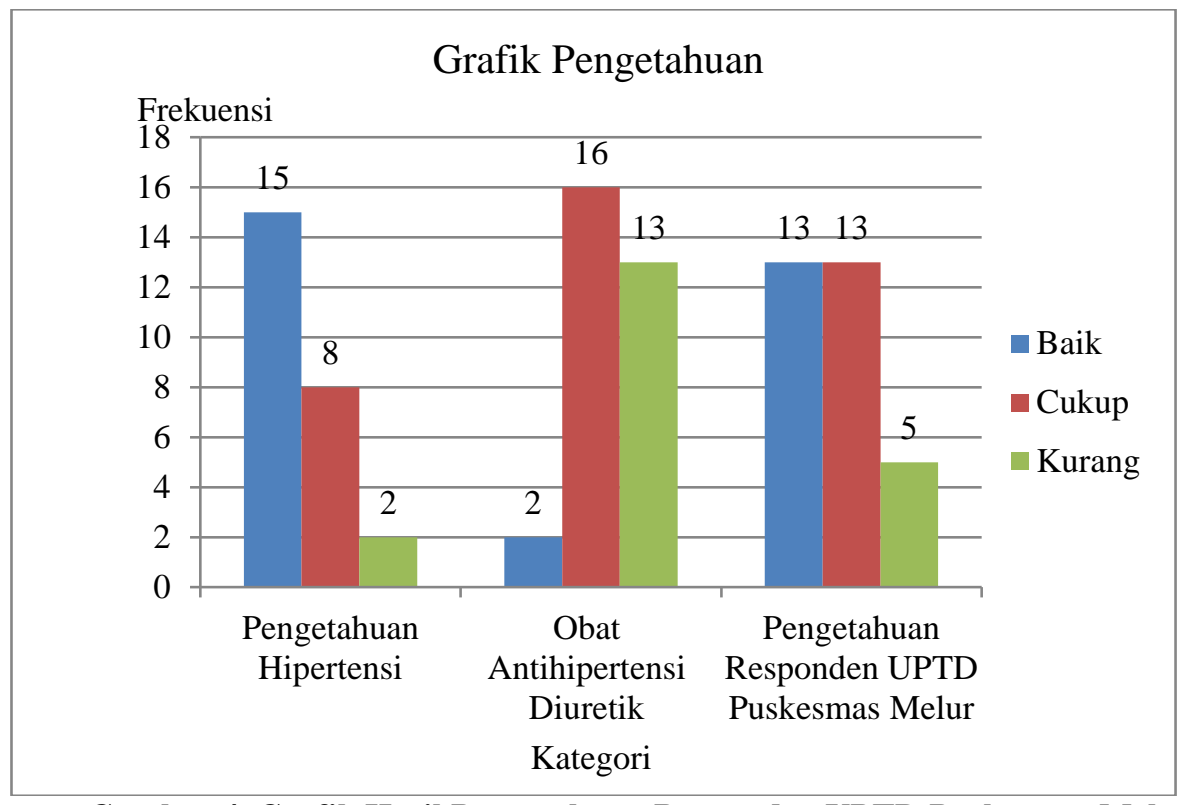

Gambar 4. Grafik Hasil Pengetahuan Responden UPTD Puskesmas Melur

Berdasarkan penelitian yang dilakukan di UPTD Puskesmas Melur, dapat dilihat pada tabel III bahwa sebagian besar responden memeriksa tekanan darah secara tidak teratur. Beberapa informasi yang diperoleh dari responden, mereka tidak teratur dalam memeriksa tekanan darah dikarenakan tidak adanya gejala yang dirasakan. Mereka akan memeriksakan tekanan darah ketika sudah tidak dapat menahan gejala yang ditimbulkan seperti pusing dan nyeri pada tengkuk akibat tekanan darah yang terlalu tinggi. Pemeriksaan darah secara teratur merupakan salah satu cara untuk mengurangi resiko komplikasi yang dapat terjadi akibat tekanan darah yang terlalu tinggi.

Berbagai macam komplikasi yang dapat terjadi akibat tekanan darah yang terlalu tinggi seperti stroke, edema, gangguan penglihatan, gagal ginjal dan jantung [4]. Menurut susilo [5], serangan hipertensi yang berulang-ulang dan lama akan meningkatkan resiko terjadinya komplikasi pada hipertensi yang dapat menyebabkan kematian. Dari penelitian yang dilakukan tidak ada responden yang menderita hipertensi lebih dari 10 tahun, hasil tersebut dapat dilihat pada tabel III. Komplikasi tersebut dapat dicegah dengan cara mengontrol tekanan darah dan menerapkan pola hidup yang sehat.

Menurut Triyanto [1], faktor umur sangat berpengaruh terhadap tekanan darah karena dengan bertambahnya umur resiko akan penyakit hipertensi semakin besar. Hal ini dikarenakan perubahan alamiah didalam tubuh yang mempengaruhi jantung, pembuluh darah dan hormon. Kondisi yang berkaitan dengan usia ini adalah produk samping dari keausan arteriosklerosis dari arteri-arteri utama, terutama aorta, dan akibat dari berkurangnya kelenturan. Dengan mengerasnya arteri-arteri ini dan menjadi semakin kaku, arteri dan aorta itu kehilangan daya penyesuaian diri. Arteri kehilangan elastisitas atau kelenturan serta tekanan darah meningkat seiring dengan bertambahnya usia. Peningkatan kasus hipertensi akan berkembang pada umur 50 dan 60 tahun. Teori ini sesuai dengan hasil penelitian, dimana sebagian besar responden yang menderita hipertensi adalah responden dengan umur 46-65 tahun seperti yang tertera pada tabel III. Selain itu, pada tabel III sebagian besar penderita hipertensi adalah perempuan. Hasil ini sesuai dengan teori yang di kemukakan oleh Marliani [6], dimana hipertensi banyak menyerang wanita setelah umur 55 tahun yaitu sekitar 60\%. Hal ini sering dikaitkan dengan perubahan hormon estrogen pada wanita setelah menopause.

Pengobatan hipertensi dilandasi oleh beberapa prinsip untuk menurunkan tekanan darah. Pengobatan hipertensi sekunder lebih mendahulukan pengobatan penyebab hipertensi. Pengobatan hipertensi esensial ditujukan untuk menurunkan tekanan darah dengan harapan memperpanjang umur dan mengurangi timbulnya komplikasi. upaya menurunkan tekanan darah dicapai dengan menggunakan obat antihipertensi. Pengobatan hipertensi adalah pengobatan jangka panjang, bahkan kemungkinan seumur hidup [8].

Dikenal 5 kelompok obat lini pertama (first line drug) yang lazim digunakan untuk pengobatan awal hipertensi, yaitu: diuretik, penyekat reseptor beta adrenergik ( $\beta$-blocker), penghambat angiotensin-converting 
enzyme (ACE-inhibitor), penghambat reseptor angiotensin (Angiotensin-receptor blocker, ARB) dan antagonis kalsium.

Golongan obat yang banyak digunakan dalam pengobatan hipertensi adalah obat antihipertensi golongan ACE-Inhibitor dan diuretik. Hal ini dikarenakan obat golongan ini dinilai paling aman dan efektif dalam menurunkan tekanan darah. Secara umum ACE-inhibitor dapat dibedakan atas dua kelompok yang pertama yaitu yang bekerja langsung contohnya kaptopril dan lisinopril. Kelompok kedua prodrug contohnya benazepril, delapril, enalapril maleat, fosinopril, perindopril, kuinapril, ramiprilat dan silazapril. Sedangkan, obat antihipertensi yang termasuk kedalam golongan diuretik antara lain: Hidrokorotiazid ${ }^{\circledR}$, Klortalidon ${ }^{\circledR}$, Xipamid $^{\circledR}$, Furosemid $^{\circledR}$, Bumetanid ${ }^{\circledR}$, Amilorid $^{\circledR}$, dan Spironolakton ${ }^{\circledR}$. Obat antihipertensi golongan diuretik ini sebaiknya di konsumsi pada pagi hari sesudah makan. Hal ini dikarenakan tekanan darah menunjukkan angka tertinggi pada pagi hari dan paling rendah adalah ketika malam hari setelah tidur. Selain itu, karena obat ini menurunkan tekanan darah melalui urin maka apabila dikonsumsi pada malam hari akan mengganggu istirahat di malam hari.

Gambaran pengetahuan pasien hipertensi terhadap penyakit hipertensi (tabel IV) dan gambaran pengetahuan pasien hipertensi terhadap obat antihipertensi golongan ACE-Inhibitor (tabel V). Dari gambar 1 dapat dilihat pengetahuan responden terhadap penyakit hipertensi sebagian besar pada kategori cukup (47\%) sedangkan pengetahuan terhadap obat golongan ACE-Inhibitor sebagian besar pada kategori kurang (60\%). Hal ini menggambarkan bahwa responden tidak terlalu ingat dengan obat yang mereka konsumsi dan lebih mengetahui tentang penyakit hipertensi.

Menurut Notoatmodjo [8], pendidikan sangat mempengaruhi tingkat pengetahuan. Semakin tinggi tingkat pengetahuan seseorang maka semakin mudah seseorang tersebut menerima informasi dari orang lain. Sebaliknya, tingkat pendidikan yang rendah akan menghambat seseorang dalam menerima informasi. Tingkat pendidikan responden dapat dilihat pada tabel III, dimana pendidikan responden sebagian besar adalah pendidikan SD (34.5\%) dan SMP (34.5\%). Namun tidak selamanya pendidikan formal menjadi tolak ukur pengetahuan, karena pengetahuan tidak hanya didapat dari pendidikan formal saja, tetapi dapat juga diperoleh dari pendidikan informal seperti pengalaman dan pergaulan dalam masyarakat. Salah satu pendidikan informal yang sering ditemukan di lingkungan masyarakat adalah pendidikan melalui penyuluhan yang merupakan strategi utama dalam pencegahan tahap primer.

Gambaran pengetahuan pasien hipertensi terhadap penyakit hipertensi (tabel IV) dan gambaran pengetahuan pasien hipertensi terhadap obat antihipertensi golongan ACE-Inhibitor (tabel VI). Dari gambar 2 dapat dilihat pengetahuan responden terhadap penyakit hipertensi sebagian besar pada kategori cukup (47\%) sedangkan pengetahuan terhadap obat golongan diuretik pada kategori cukup (52\%) dan kategori kurang (42\%) memiliki nilai yang tidak jauh berbeda. Hal ini menggambarkan bahwa responden cukup mengetahui dengan obat golongan diuretik dibandingkan dengan obat golongan ACE-Inhibitor yang mereka konsumsi dan lebih mengetahui tentang penyakit hipertensi.

\section{KESIMPULAN}

Dari hasil penelitian ini dapat disimpulkan bahwa pengetahuan pasien tentang penyakit hipertensi pada kategori cukup (47\%) dan pengetahuan pasien tentang obat golongan ACE-Inhibitor pada kategori kurang $(60 \%)$ sedangkan pengetahuan pasien tentang obat golongan diuretik pada kategori cukup (52\%).

\section{UCAPAN TERIMA KASIH}

Terimakasih kepada Fitri dan Widya yang telah membantu terlaksananya penelitian ini

\section{DAFTAR PUSTAKA}

1. Triyanto, E. 2014. Pelayanan Keperawatan Bagi Penderita Hipertensi Secara Terpadu. Yogyakarta: Graha Ilmu

2. Mohani, C.I. 2014. Management Of Hypertension In Anherosclerotic Cardiovascular Disease, Symposium On Hypertension. Jakarta: PENEFRI

3. Fitrianto, H., Syaiful Azmi, dan Husnil Kadri. Penggunaan Obat Antihipertensi pada Pasien Hipertensi RSUP DR. M. Djamil Tahun 2011. 2014. http://jurnal.fk.unand.ac.id. (diakses 1 september 2014) 
4. Factor, S. M., Abadi, M.A.L., Abadi, J.2002. Handbook of Pathology and Pathophysiology of cardiovascular Disease. New York: Kluwer Academic Publisher

5. Susilo, Y., dan Ari Wulandari. 2011. Cara Jitu Mengatasi Hipertensi. Yogyakarta: Andi

6. Marliani, L., dan Tantan S. 2007. 100 Question \& Answers Hipertensi. Jakarta: Elex Media Komputindo

7. Wells, B. G., J. T. Dipiro., T. L. Schwinghammer and C. W. Hamilta. 2006. Pharmacotherapy Handbook (Edisi 6) Cetakan IV. New York: The McGraww Hill Co.

8. Notoatmodjo, S. 2010. Promosi Kesehatan Teori dan Aplikasinya. Jakarta: Rineka Cipta

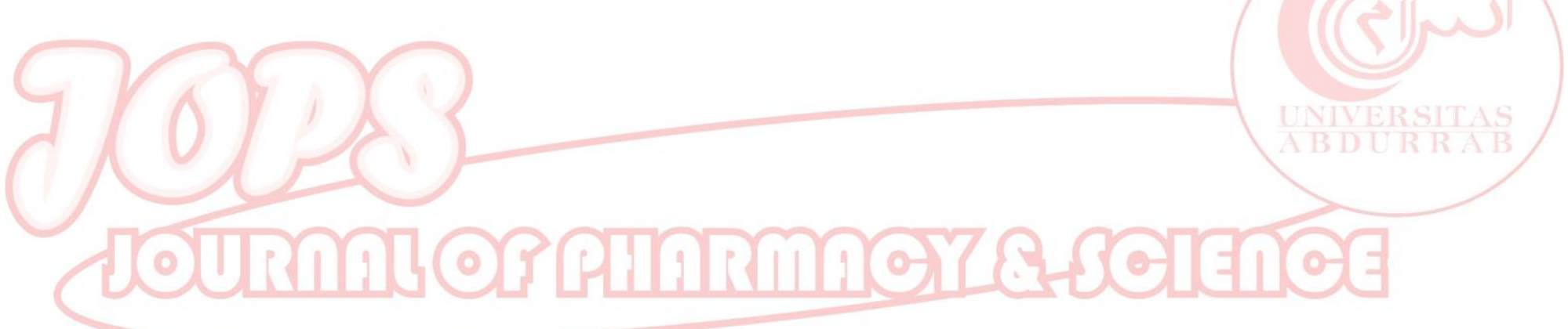

